\title{
Taxonomic and Ecological Significance of Foliar Epidermal Characters in Four Taxa of Mussaenda L. (Rubiaceae) in Nigeria
}

\author{
Felix Ifeanyi Nwafor ${ }^{1^{*}}$, Maria O. Nwosu ${ }^{2}$ and Amarachi Z. Nwafor ${ }^{2}$ \\ ${ }^{1}$ Department of Pharmacognosy and Environmental Medicines, University of Nigeria, Nsukka, Nigeria. \\ ${ }^{2}$ Department of Plant Science and Biotechnology, University of Nigeria, Nsukkka, Nigeria.
}

Authors' contributions

This work was carried out in collaboration between all authors. All authors read and approved the final manuscript.

Article Information

DOI: $10.9734 / A R R B / 2019 / v 32 i 530100$ Editor(s):

(1) Dr. George Perry, Dean and Professor of Biology, University of Texas at San Antonio, USA. Reviewers:

(1) Folorunso Abayomi Ezekiel, Obafemi Awolowo University, Nigeria. (2) Alok Nahata, Ying Zhi Agricultural and Industries Sdn Bhd, Malaysia. (3) Suoyi Han, Industrial Crops Research Institute, Henan Academy of Agricultural Sciences, China. Complete Peer review History: http://www.sdiarticle3.com/review-history/47057

Original Research Article

Received 17 December 2018

Accepted 03 February 2019

Published 21 August 2019

\section{ABSTRACT}

Aims: This study investigated leaf epidermal features as taxonomic markers in delimiting two West African species (M. elegans and $M$. erythrophylla) and two Philippine infraspecific species ( $M$. "Doña Aurora" and M."Doña Luz") of Mussaenda L. in Nigeria and their ecological significance.

Study Design: The experiment adopted a Completely Block Design (CBD) of four plant taxa from two study locations with 10 replicates each, totaling 80 samples.

Place and Duration of Study: The study was carried out in the Department of Plant Science and Biotechnology, University of Nigeria, Nsukka, between June and September, 2010.

Methodology: Fresh leaves were collected from the Tropical Rainforest (TRF) and Derived Savanna (DS) vegetations of Nigeria under the same weather conditions. Leaf epidermal strips were prepared by clearing method, stained with Safranin and observed under the light microscope.

Results: The stomata are of the paracytic type borne on polygonal to irregularly shaped, wavy epidermal cells. Simple trichomes were also a common feature in all taxa. Mussaenda erythrophylla has significantly $(P<0.05)$ the least dense stomata $\left(84.51 \pm 0.73 \mathrm{~mm}^{-2}\right)$ while $M$. "Doña Aurora" has the densest stomata $\left(230.98 \pm 2.67 \mathrm{~mm}^{-2}\right)$. M. elegans and $M$. "Doña Aurora" have significantly the 
highest stomata index $(28.48 \%$ and $28.98 \%$ respectively) while $M$. "Doña Luz" has the lowest $(24.31 \%)$. Samples from the TRF have significantly higher density, index and size of stomata in $M$. elegans and M. "Doña Luz" than those from DS. Quantitative trichome parameters also vary among the taxa. The fewest trichomes were observed in $M$. elegans $(7.90 \pm 0.14$ and $11.75 \pm 0.21)$ while they are most abundant in $M$. "Doña Luz" (11.77 \pm 0.11 and $18.90 \pm 0.51)$. Ecological conditions affected these variables as trichomes were more abundant in the specimens collected from DS locations.

Conclusion: Epidermal features are proven significant tools in taxonomic delimitation and as environmental indicators in predicting climatic changes and environmental pollution.

Keywords: Taxonomy; ecology; leaf epidermal characters; stomata; Mussaenda; Rubiaceae; Nigeria.

\section{INTRODUCTION}

The genus Mussaenda L. belongs to the family Rubiaceae and includes about 200 species with geographical spread from Africa to Asia, New Guinea and Australia [1]. They are tropical evergreen shrubs and scrambling climbers grown for their long-lasting showy flowers [2]. The usual distinguishing feature of this genus is the possession of one (or five in some cultivars) enlarged petaloid sepals called calycophylls. These calycophylls are mistaken for bracts in many publications $[1,2]$.

Ornamental Mussaenda species are considered one of the most significant contributions of the floriculture industry. Records also show that its demand for cut flowers and landscape plants has undoubtedly increased in recent past [3]. In Nigeria's landscapes, they flower luxuriantly for almost throughout the year, and other shrubs cannot compete favourably with Mussaendas in effectiveness of display of colour when in bloom [4]. They have proved to be among the most popular, demanded and used flowering shrubs in the warm humid tropical regions $[5,6,7]$. They are also used in folk medicine for the treatment of boils [8], vomiting, malaria, dysentery, stomach ache and fever [9]. Vidyalakshmi et al. [10] reported diuretic, antiphlogistic, antipyretic, laryngopharyngitis, anti-fertility and antiviral activities from the different species of Mussaenda.

Despite the wide distribution, socio-economic uses and potential benefits of this genus, a lot of controversies still exist in their circumscription, and a search in the literature shows paucity of information on the proper identification and nomenclature of the country's cultivated garden Mussaendas [4,11]. While $M$. elegans and $M$. erythrophylla originated from West Africa, $M$. "Doña Aurora" and M. "Doña Luz" are variants (or cultivars) of M. philippica that is of Philippine origin. The variants, $M$. "Doña Aurora" and $M$. "Doña Luz", like so many other cultivars, were named in honour of the wives of the Presidents of Philippine, Mrs Aurora Quezon and Mrs Luz Magsaysay respectively [11]. However, available literatures on the plants are scanty and revealed mixed up of identities as almost all the distinct ornamental species grown in gardens are all regarded as 'Queen of the Philippine' (the official common name for $M$. philippica) [4,12]. As a matter of fact, "Doña Aurora" is the most widely known and cultivated among the Mussaendas. Other hybrids include "Doña Queen Sirikit", "Doña Esperanza", "Doña Hilaria" "Paraluman" and so on [11].

Traditionally, plant taxonomy has depended mainly upon comparative morphological features because these are easily observable in the living plants with the use of hand lens or, at the most, a dissecting microscope as equipment $[13,14]$. Micro-morphological features, especially leaf epidermal characters, have played an increasingly important role in taxonomic distinction and recognition in Rubiaceae [15]. The major diagnostic features include the morphology, types and sizes of epidermal cells, stomata and trichomes [15,16,17]. Representatives of multiple epidermal types may be found in species of Moraceae, Piperaceae, Bignoniaceae, Malvaceae and in most Monocots [18]. In leaves, stomata may occur on both surfaces (amphistomatic leaf) or on only one, either the upper (epistomatic leaf) or more commonly on the lower (hypostomatic) $[13,18]$. Stomatal types vary amongst plant taxa for example, anomocytic type, anisocytic type, diacytic type, paracytic type usually found in Rubiaceae, actinocytic type and cyclocytic $[13,18]$. Quantitative stomatal parameters of taxonomic importance are stomatal size, stomatal index and stomatal number. Leaf hairs (trichomes) can also vary considerably in density and morphology among species of plants, and 
may also vary among populations and within individual plants. Their structure can range from unicellular to multicellular, and can be branched, or un-branched $[13,18]$.

Leaf epidermal features are also affected by climatic and environmental changes and thus could be used as indicators for environmental monitoring $[19,20]$. Their distribution, density and size can be influenced by climatic factors such as humidity, temperature, light intensity and atmospheric $\mathrm{CO}_{2}[21,22]$. For example, highcanopy trees are more exposed to light intensity and tend to have denser stomata than undergrowth plants. Furthermore, amphistomaty in leaves could be partly influenced by high irradiance [23]. Leaf trichomes function in defence, but also affect gas exchange and temperature. In many plants, trichomes decrease the absorption of shortwave radiation by leaves and keep them cooler [21]. For this reason, plants that found themselves in unfavorable growth conditions would produce more trichomes as an adaptation strategy for their survival.

Nigeria is a country located in West Africa with a total area of $923,768 \mathrm{~km}^{2}$ and population estimated around 198, 577, 125. Nigeria lies between latitudes $4^{\circ}$ and $14^{\circ} \mathrm{N}$, and longitudes $2^{\circ}$ and $15^{\circ} \mathrm{E}$ with three main vegetation zones rainforest, savanna and montane. This study was carried out in two different vegetation area - Uyo and Nsukka. Uyo is a city in south-eastern Nigeria and is the capital of Akwa Ibom State, a major crude oil producing State of Nigeria. It is located on Latitude $6^{\circ} 03^{\prime} 4.57^{\prime \prime} \mathrm{N}$ and Longitude $7^{\circ} 56^{\prime} 0.60^{\prime \prime} \mathrm{E}$. This city has a tropical rainforest climate with average annual rainfall of $2509 \mathrm{~mm}$. The average annual temperature in Uyo is $26 \cdot 4^{\circ} \mathrm{C}$. Rainfall averages $2509 \mathrm{~mm}$ [24,25]. Nsukka has an area of $1,810 \mathrm{~km}^{2}$, located on Latitude $6.5124^{\circ} \mathrm{N}$ and Longitude $7.2345^{\circ} \mathrm{E}$. Vegetation is characteristically derived savanna. The annual rainfall ranges from 1,845 - 2000 $\mathrm{mm}$. Annual temperature is between $25^{\circ} \mathrm{C}$ and $27^{\circ} \mathrm{C}[24]$.

Therefore, this study investigated leaf epidermal features in two West African species ( $M$. elegans and $M$. erythrophylla) and two infraspecific Philippine species (cultivars - M. "Doña Aurora" and M. "Doña Luz") of Mussaenda L. across the tropical rainforest and derived savanna vegetation zones of Nigeria for their potential as tools for taxonomic delimitation and environmental monitoring.

\section{METHODOLOGY}

This study was carried out in the Plant Anatomy/Taxonomy Laboratory, Department of Plant Science and Biotechnology (formerly Department of Botany), University of Nigeria, Nsukka. The field collections and experiments were conducted between June and September, 2017.

\subsection{Plant Materials}

Fresh leaves of the four Mussaenda taxa were used for the study. They were collected from Uyo and Nsukka metropolises of Nigeria, representing both Tropical rainforest and Derived savanna ecological zones of Nigeria respectively. Collections were performed simultaneously at both locations during the rainy season. On-field identification and macro-morphological features of the samples were carried out and recorded. Species identity were confirmed following the taxonomic Keys of Flora of West Tropical Africa [26] and comparison with the Type Specimens on databases of Kew Herbarium, England [27] and the New York Botanic Garden [28].

\subsection{Isolation of Leaf Epidermises}

Clearing method was used as described by Ogbonna et al. [20] with slight modifications. Fresh leaves were soaked in commercial bleach (Hypo®) containing $3.5 \%$ sodium hypochlorite for a period ranging from 14 to 18 hours according to the nature of the respective leaf samples. The cleared leaves were pulled out and rinsed thrice with tap water. The leaf epidermises were then scraped with a sharp blade and further washed in tap water with Camel's hair brush.

\subsection{Preparation of Slides}

Both the adaxial and abaxial epidermises of each of the samples were placed on a clean microscopic glass slide, stained with Safranin solution and $10 \%$ glycerine was dropped before placing a cover slip. This was sealed with nail hardener to prevent the preparation from drying up. They were observed under the light microscope (Make: Olympus Tokyo; Model: Japan No. 271961) at x4, x10 and $\times 40$ objectives.

\subsection{Scoring of Epidermal Parameters and Photomicrograph of Slides}

The following parameters were observed and assessed according to the terminologies of Evert 
[18]. Means of quantitative measurements were calculated from a total of 10 observations for each sample. Photomicrographs were taken with Motic camera attached to the microscope.

1. Epidermal cells: the epidermal cells were counted and their types/shapes were recorded.

2. Stomata: the stomatal complex types were observed and recorded. Stomata density was determined as the number of stomata per square millimetre. Stomata sizes (length, width and area) were measured using the Motic software. Stomatal index was determined by the following expression:

$$
\text { Stomata Index (\%) }=\frac{S_{n}}{S_{n}+E_{n}} \times 100
$$

Where: $S_{n}$ and $E_{n}$ stand for stomata number and epidermal cells number respectively in a given area [29].

3. Trichome: the trichome types, size, density and index were determined following the same procedures as the stomata above [30].

\subsection{Statistical Analyses}

Analysis of Variance (ANOVA) using the Statistical Package for Social Sciences (SPSS version 20) was used to test significance (at $P \leq$ 0.05 ) of means of the variables while Duncan's Multiple Range Test (DMRT) was used for mean separation. Students' independent sample T-test was used to compare means of data from the two ecological study locations at $\mathrm{P} \leq 0.05$.

\section{RESULTS AND DISCUSSION}

This study was aimed at using leaf epidermal features as a line of evidence in delimiting two West African species ( $M$. elegans and $M$. erthrophylla) and two infraspecific Philippine species (M. philippica var. aurorae and $M$. philippica var."Doña Luz") of Mussaenda that occurr in Nigeria. On-field observation revealed the individual taxon differs from others in their habits, colours of their petals (orange in $M$. elegans, red in $M$. erythrophylla, yellow in $M$. "Doña Aurora" and $M$. "Doña Luz), colour and presence or absence of petaloid sepals (petaloid sepal absent in M. elegans but present in others; red in $M$. erythrophylla, creamy white in $M$. "Doña Aurora" and pink in $M$. "Doña Luz), and in the leaf architectural patterns (Plate 1). This is in agreement with the botanical descriptions of these plants as reported by Hutchinson and Dalziel [26], Kpadehya and Bout Jr. [1] and Stuart [31]. It is important to note that none of these features were influenced by climatic conditions as individual specimens collected from both study locations shared major morphological features and it could be inferred that they are genetically predetermined, hence, very useful taxonomic tools.

\subsection{Epidermal Cells}

The result of the comparative study of the epidermal cells in the four taxa showed some similarities and dissimilarities in shapes and nature of the anticlinal cell walls of the epidermises especially on the adaxial sides. The epidermal cells are polygonal to less undulating with thick cell wall in $M$. elegans; irregular and clearly undulating with thin cell wall in $M$. erythrophylla; and irregular to less undulating with thick cell walls in $M$. "Doña Aurora" and $M$. "Doña Luz" (Plates 2 and 3). On the abaxial surfaces, the epidermal cells are polygonal in "Doña Aurora" but, irregular and clearly undulating in others (Plates 6 and 7). $M$. erythrophylla possesses significantly $(P<0.05)$ the lowest number of epidermal cells (47.00 \pm 0.84 and $46.00 \pm 1.14$ on the adaxial and abaxial surfaces respectively) per field of view, whereas, M. "Doña Aurora" has the largest number (98.80 \pm 0.74 and $95.80 \pm 1.43$ on the adaxial and abaxial surfaces respectively) (Table 1). Furthermore, epidermal cells are significantly $(P<$ .05) more on the adaxial surface than on the abaxial surface in both $M$. elegans and $M$. "Doña Luz" but do not differ in others. It is inferred that environment does not significantly affect the epidermal cell features as samples collected from both study locations gave similar results. These results confirm the contribution of epidermal cell pattern and configuration as important taxonomic tool to distinguish Mussaenda at both the infrageneric and infraspecific levels. Our findings also support those reported by earlier researchers $[29,32,33]$.

\subsection{Stomata Types and Measurements}

The results from this study show that the four taxa studied were all hypostomatic (i.e. stomata occur only on the lower/abaxial surfaces) and possessed paracytic type of stomata (Plates 6 
and 7) that is characteristic of the Rubiaceae $[16,29,34]$. This agrees with the findings of Obembe [29] who reported paracytic stomata in $M$. elegans, $M$. chippi and $M$. landolphoides. However, the individual plants differed from one another in quantitative stomata parameters such as the stomata density, index and size. Mussaeda erythrophylla has significantly $(P<$

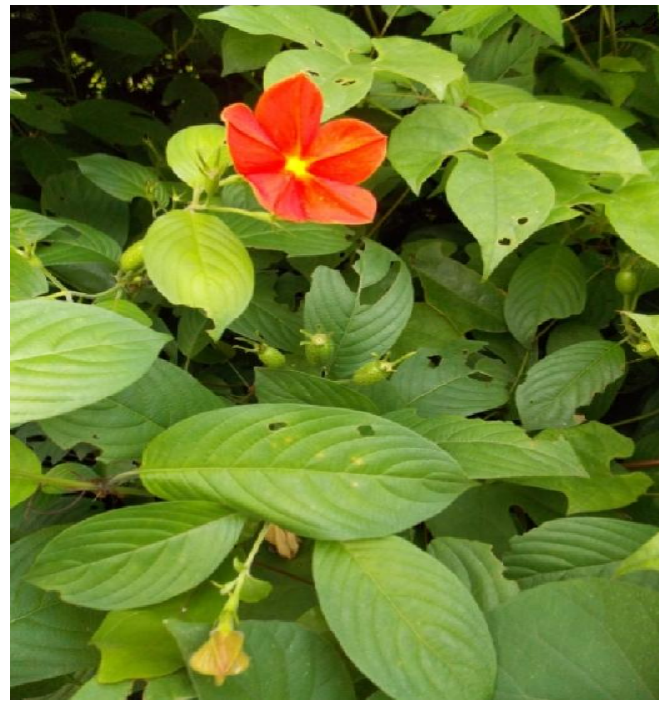

A

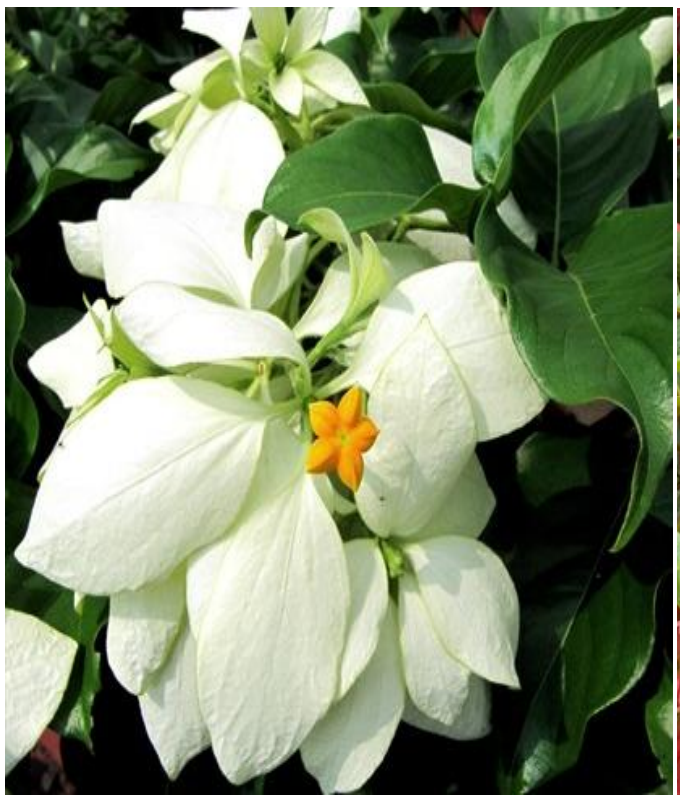

C
$.05)$ the least dense stomata $\left(84.51 \pm 0.73 \mathrm{~mm}^{-2}\right)$ while $M$. "Doña Aurora" had the densest stomata $\left(230.98 \pm 2.67 \mathrm{~mm}^{-2}\right)$. Mussaenda elegans and $M$. "Doña Aurora" had significantly the highest value for stomata index $(28.48 \%$ and $28.98 \%$ respectively) while $M$. "Doña Luz" has the lowest $(24.31 \%)$. Stomata size also varied significantly (Table 2).

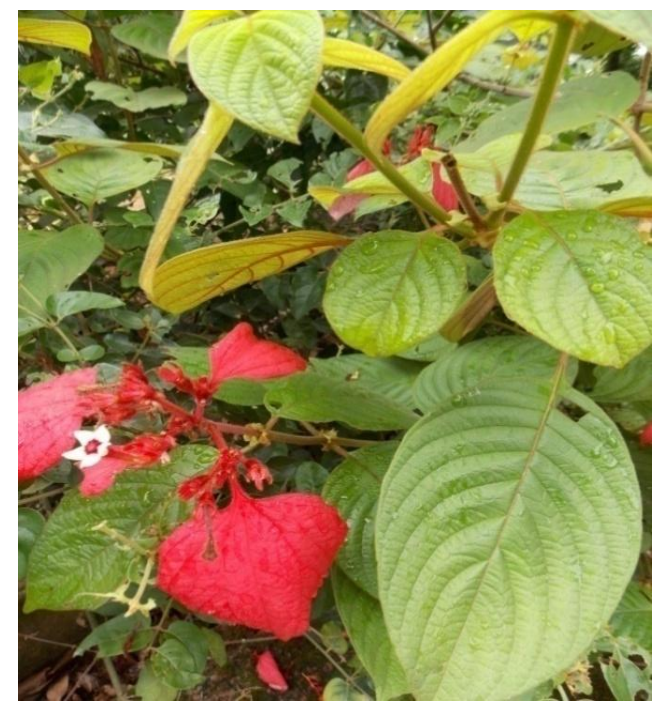

B

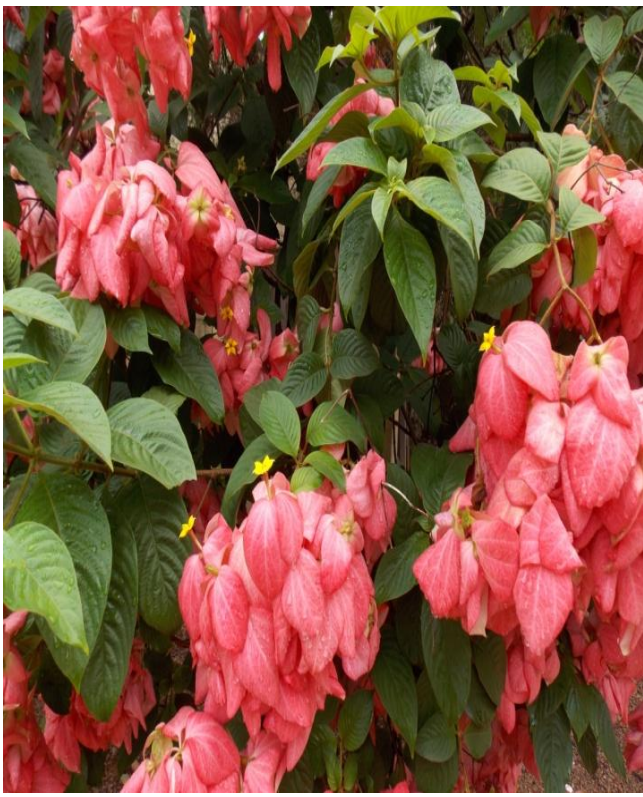

D

Plate 1. Morphology of the four taxa of Mussaenda; $\mathrm{A}=$ M. elegans; $\mathrm{B}=$ M. erythrophylla; $\mathrm{C}=M$. 'Doña Aurora'; $\mathrm{D}=\mathrm{M}$. 'Doña Luz' 


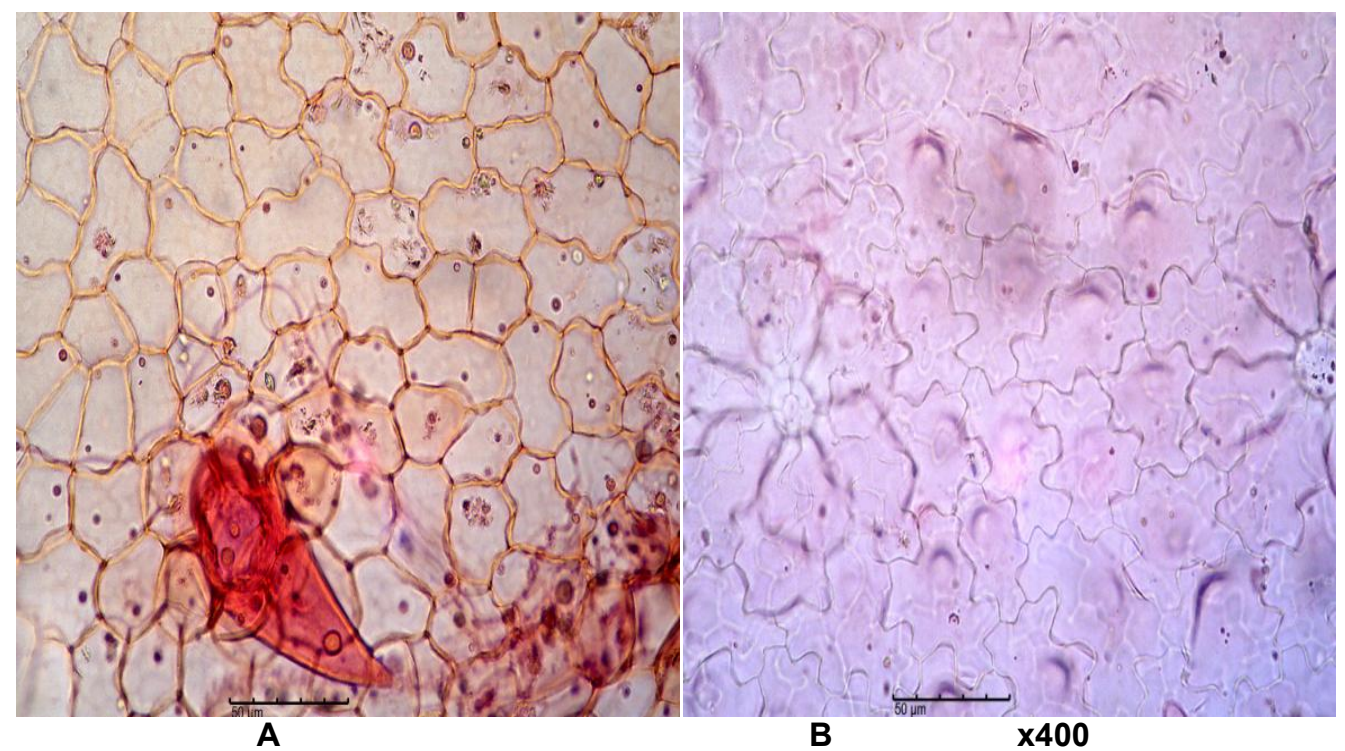

Plate 2. Epidermal cells of the leaves of (A): $M$. elegans and (B): $M$. erythrophylla

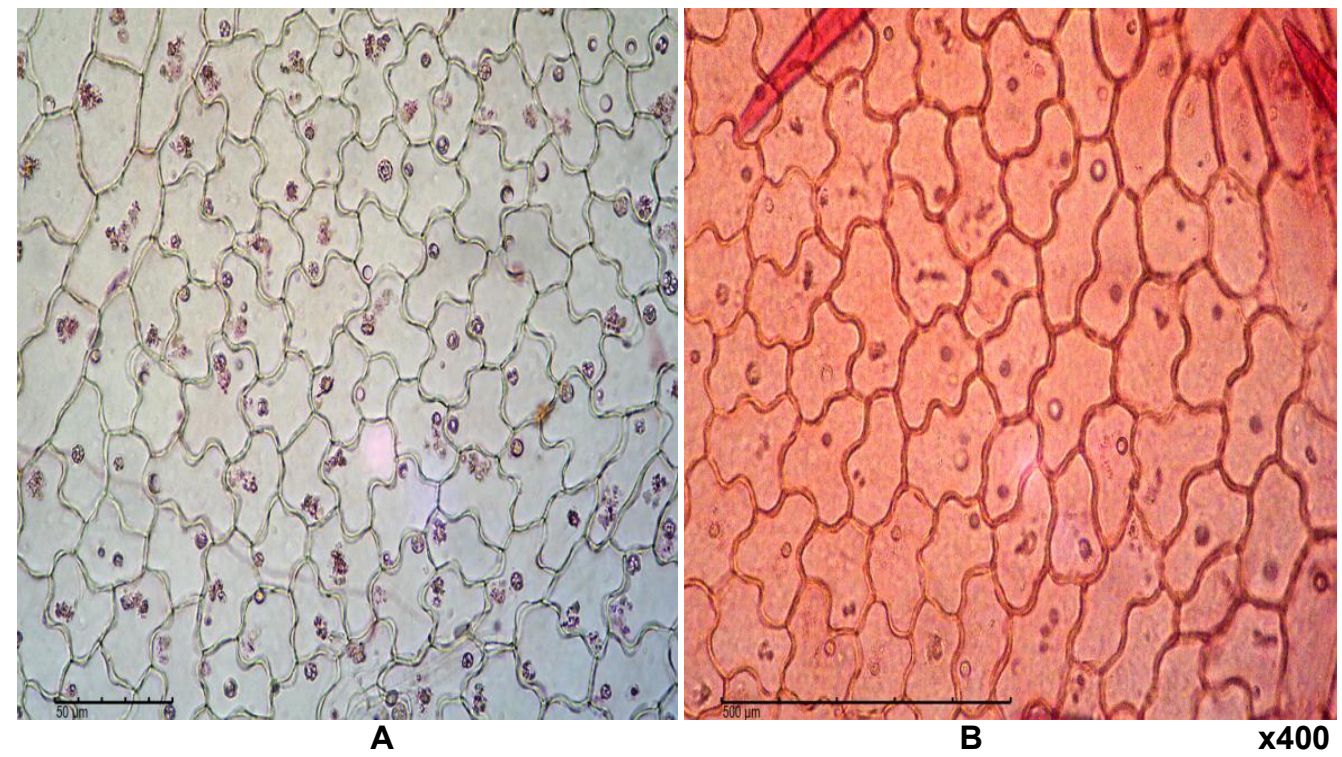

Plate 3. Epidermal cells of the leaves of (A): M."Doña Aurora" and (B): $M$. "Doña Luz" Table 1. Variation of epidermal cell number per field of view in the study plants

\begin{tabular}{lll}
\hline Sample & Adaxial Surface & Abaxial Surface \\
\hline M. elegans & $80.20 \pm 0.74^{\mathrm{b}_{*}}$ & $68.20 \pm 1.11^{\mathrm{b}}$ \\
M. erythrophylla & $47.00 \pm 0.84^{\mathrm{d}}$ & $46.00 \pm 1.14^{\mathrm{c}}$ \\
M.“DoñaAurora" & $98.80 \pm 0.74^{\mathrm{a}}$ & $95.80 \pm 1.43^{\mathrm{a}}$ \\
M. "Doña Luz" & $70.00 \pm 0.45^{\mathrm{C}_{*}}$ & $67.80 \pm 0.58^{\mathrm{b}}$ \\
\hline
\end{tabular}

Mean \pm S.E.M $=$ Mean values \pm Standard error of means of 10 experiments

Means with different letters as superscripts along a column are significantly different $(P<0.05)$

* Significantly different at $P<0.05$

The specimens collected from the Rainforest (wetter) area had higher values for stomatal density, stomatal index and stomatal size than those from the savanna (Table 3 ). This could be as a result of adaptation to change in environmental (ecological) conditions. Stomata 
serve primarily for gaseous exchange in plants [18]. Their density can be influenced by humidity, temperature, light intensity and atmospheric $\mathrm{CO}_{2}$ $[21,22]$. Plants in drier regions tend to have reduced stomatal density to conserve water. Uyo (the Rainforest area), being a cosmopolitan city would have higher amount of atmospheric $\mathrm{CO}_{2}$ (from exhaust pipes etc.) which might have consequently contributed to higher stomatal densities in the Rainforest samples [23]. Higher stomata size recorded for $M$. "Doña Aurora" collected from the wetter region could be attributed to higher osmotic potential as expected in plants grown in less stressed environment [18]. This result agrees with those of previous authors $[19,20]$ who reported differences in stomata in plants collected from polluted areas and suggested their potential in environmental monitoring.

\subsection{Trichome Types and Measurements}

This study showed that the epidermises are covered with trichomes (i.e. pubescent) which are simple, multicellular and uniseriate in all the taxa. Glandular trichomes were not observed (Plates 4 and 5). Again, the plants differ from one another in terms of density, index and size of trichomes present; these differences were also observed on the adaxial and abaxial surfaces of same taxon. The fewest trichomes were found in $M$. elegans $(7.90 \pm 0.14$ and 11.75 \pm 0.21 on the adaxial and abaxial surfaces respectively) while they were most abundant in $M$. "Dona Luz" (11.77 \pm 0.11 and $18.90 \pm$ 0.51 on the adaxial and abaxial surfaces respectively) (Table 4). This could be employed as important taxonomic tool in the delimitation of the taxa.

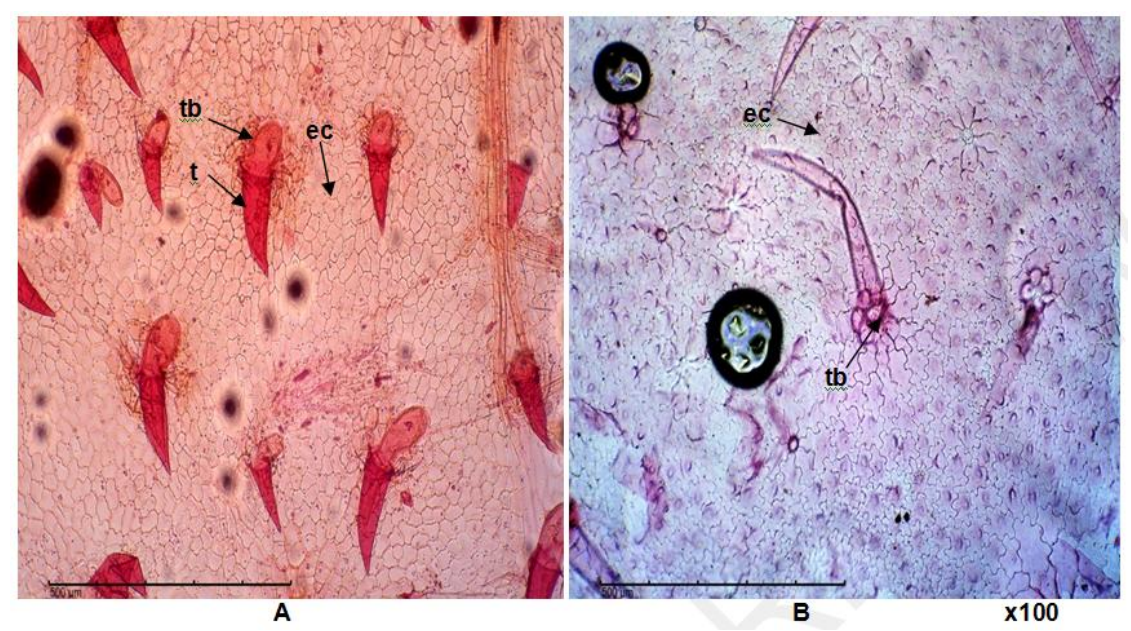

Plate 4. Adaxial surfaces of the leaves of (A): $M$. elegans and (B): $M$. erythrophylla

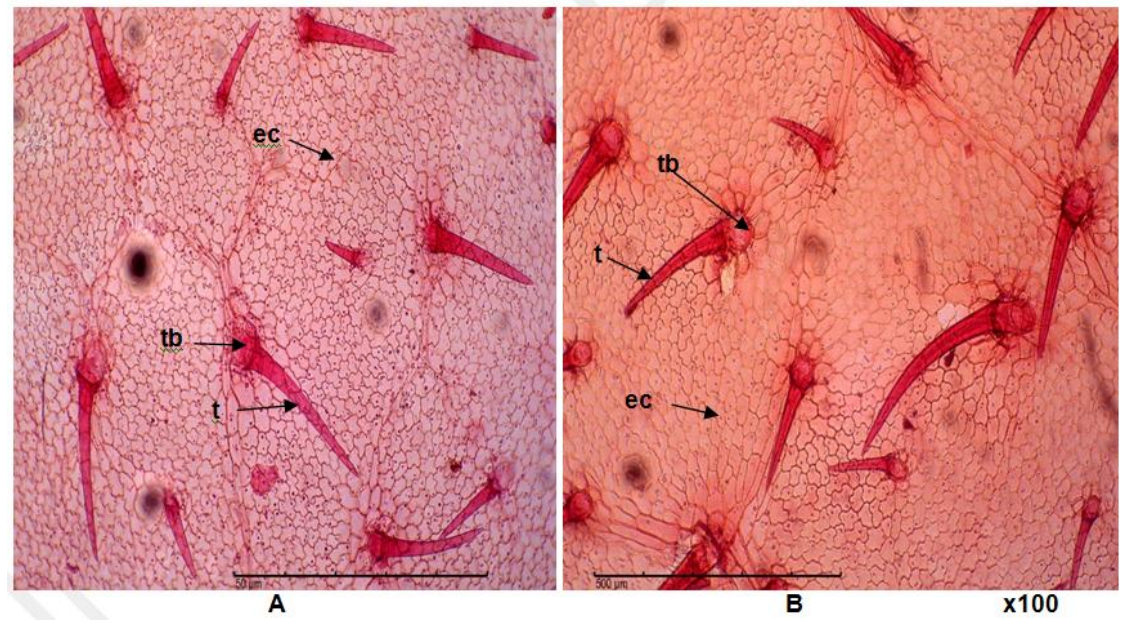

Plate 5. Adaxial surfaces of the leaves of (A): $M$. "Doña Aurora" and (B): $M$. "Doña Luz" ec = epidermal cell; $t=$ trichome; $t b=$ trichome base 
Table 2. Quantitative stomata parameters of the four Mussaenda taxa

\begin{tabular}{|c|c|c|c|c|}
\hline Parameter & M. elegans & M. erythrophylla & M. "Doña Aurora" & M. “Doña Luz" \\
\hline Number & $18.80 \pm 0.17^{\mathrm{C}}$ & $14.37 \pm 0.12^{\mathrm{d}}$ & $39.27 \pm 0.46^{a}$ & $21.55 \pm 0.23^{b}$ \\
\hline Density (mm- $\left.{ }^{2}\right)$ & $110.59 \pm 1.00^{c}$ & $84.51 \pm 0.73^{\mathrm{d}}$ & $230.98 \pm 2.67^{\mathrm{a}}$ & $126.76 \pm 1.34^{b}$ \\
\hline Index (\%) & $28.48 \pm 0.16^{\mathrm{a}}$ & $25.47 \pm 0.16^{\mathrm{b}}$ & $28.98 \pm 0.24^{\mathrm{a}}$ & $24.31 \pm 0.21^{\mathrm{c}}$ \\
\hline Length (mm) & $23.33 \pm 0.26^{b}$ & $24.48 \pm 0.36^{a}$ & $20.25 \pm 0.40^{\mathrm{d}}$ & $22.13 \pm 0.19^{c}$ \\
\hline Breadth (mm) & $13.13 \pm 0.39^{a}$ & $13.92 \pm 0.11^{a}$ & $13.24 \pm 0.32^{a}$ & $11.02 \pm 0.18^{b}$ \\
\hline Size $\left(\mathrm{mm}^{2}\right)$ & $310.58 \pm 11.44^{b}$ & $341.01 \pm 5.71^{a}$ & $271.09 \pm 10.24^{c}$ & $245.11 \pm 5.66^{d}$ \\
\hline
\end{tabular}

Table 3. Quantitative stomata parameters of the four taxa across the two locations

\begin{tabular}{|c|c|c|c|c|c|c|c|c|}
\hline Parameter & M. eleg & & M. erythrop & hylla & M. "Doña A & rora" & M. "Doña & uz" \\
\hline Locations & DS & RF & DS & RF & DS & RF & DS & RF \\
\hline Number & $18.13 \pm 0.20$ & $19.47 \pm 0.22^{*}$ & $14.17 \pm 0.15$ & $14.57 \pm 0.19$ & $38.77 \pm 0.67$ & $39.77 \pm 0.61$ & $20.40 \pm 0.27$ & $22.70 \pm 0.22^{*}$ \\
\hline Density $\left(\mathrm{mm}^{2}{ }^{2}\right)$ & $106.67 \pm 1.15$ & $114.51 \pm 1.28^{*}$ & $83.33 \pm 0.90$ & $85.68 \pm 1.12$ & $228.04 \pm 4.00$ & $233.92 \pm 3.59$ & $120.00 \pm 1.59$ & $133.53 \pm 1.30^{*}$ \\
\hline Index (\%) & $27.82 \pm 0.21$ & $29.13 \pm 0.17^{*}$ & $25.21 \pm 0.20$ & $25.73 \pm 0.25$ & $28.71 \pm 0.36$ & $29.25 \pm 0.32$ & $23.32 \pm 0.23$ & $25.29 \pm 0.19^{*}$ \\
\hline Length (mm) & $22.72 \pm 0.39$ & $23.93 \pm 0.32^{*}$ & $24.40 \pm 0.52$ & $24.55 \pm 0.50$ & $20.00 \pm 0.56$ & $20.50 \pm 0.58^{*}$ & $21.67 \pm 0.24$ & $22.59 \pm 0.29^{\star}$ \\
\hline Breadth (mm) & $11.62 \pm 0.57$ & $14.65 \pm 0.37^{*}$ & $13.94 \pm 0.15$ & $13.91 \pm 0.15$ & $13.05 \pm 0.46$ & $13.43 \pm 0.47$ & $10.36 \pm 0.12$ & $11.68 \pm 0.30^{*}$ \\
\hline Size $\left(\mathrm{mm}^{2}\right)$ & $268.58 \pm 16.36$ & $352.59 \pm 11.95^{*}$ & $340.43 \pm 8.30$ & $341.59 \pm 7.98$ & $262.43 \pm 13.17$ & $279.75 \pm 15.74$ & $224.93 \pm 4.32$ & $265.29 \pm 9.14^{*}$ \\
\hline
\end{tabular}

$D S=$ Derived Savanna; RF = Rainforest; Mean \pm S.E.M = Mean values \pm Standard error of means of 10 experiments; ${ }^{*}$ Significantly different at $P<0.05$ across a row

Table 4. Quantitative trichome parameters of the four Mussaenda taxa

\begin{tabular}{|c|c|c|c|c|c|c|c|c|}
\hline \multirow[t]{2}{*}{ Taxa } & \multicolumn{2}{|c|}{ Number } & \multicolumn{2}{|c|}{ Density $\left(\mathrm{mm}^{-2}\right)$} & \multicolumn{2}{|c|}{ Index (\%) } & \multicolumn{2}{|c|}{ Size $(\mu \mathrm{M})$} \\
\hline & Adaxial & Abaxial & Adaxial & Abaxial & Adaxial & Abaxial & Adaxial & Abaxial \\
\hline MEL & $7.90 \pm 0.14^{\mathrm{d}}$ & $11.75 \pm 0.21^{\mathrm{d}}$ & $2.52 \pm 0.44^{\mathrm{d}}$ & $3.74 \pm 0.67^{\mathrm{d}}$ & $0.53 \pm 0.01^{\mathrm{c}}$ & $1.30 \pm 0.02^{d}$ & $162.54 \pm 13.64^{\mathrm{C}}$ & $287.48 \pm 17.73^{b}$ \\
\hline MER & $10.47 \pm 0.09^{b}$ & $39.20 \pm 0.16^{b}$ & $3.34 \pm 0.03^{b}$ & $12.75 \pm 0.90^{b}$ & $1.30 \pm 0.01^{a}$ & $4.81 \pm 0.02^{a}$ & $307.70 \pm 15.28^{a}$ & $377.56 \pm 25.40^{a}$ \\
\hline MxDA & $9.63 \pm 0.09^{c}$ & $41.25 \pm 0.24^{a}$ & $3.07 \pm 0.29^{c}$ & $13.41 \pm 0.07^{a}$ & $0.54 \pm 0.01^{c}$ & $2.27 \pm 0.01^{\mathrm{b}}$ & $235.65 \pm 9.33^{b}$ & $326.76 \pm 5.25^{\mathrm{ab}}$ \\
\hline MxDL & $11.77 \pm 0.11^{\mathrm{a}}$ & $18.90 \pm 0.51^{\mathrm{c}}$ & $3.75 \pm 0.06^{a}$ & $6.02 \pm 0.16^{c}$ & $0.92 \pm 0.01^{b}$ & $1.50 \pm 0.04^{c}$ & $251.53 \pm 12.56^{b}$ & $377.56 \pm 25.40^{a}$ \\
\hline
\end{tabular}


Table 5. Quantitative trichome parameters of the four taxa across the two locations

\begin{tabular}{|c|c|c|c|c|c|c|c|c|}
\hline \multirow[t]{2}{*}{ Taxa } & \multicolumn{2}{|c|}{ Number } & \multicolumn{2}{|c|}{ Density $\left(\mathrm{mm}^{2}\right)$} & \multicolumn{2}{|c|}{ Index (\%) } & \multicolumn{2}{|c|}{ Size $(\mu \mathrm{m})$} \\
\hline & Adaxial & Abaxial & Adaxial & Abaxial & Adaxial & Abaxial & Adaxial & Abaxial \\
\hline MEL-DS & $8.70 \pm 0.15$ & $12.67 \pm 0.30^{*}$ & $2.77 \pm 0.05$ & $4.03 \pm 0.10^{*}$ & $0.59 \pm 0.01$ & $1.40 \pm 0.33^{*}$ & $165.77 \pm 18.10$ & $325.05 \pm 32.42$ \\
\hline MEL-RF & $7.10 \pm 0.10$ & $10.83 \pm 0.18$ & $2.26 \pm 0.03$ & $3.45 \pm 0.06$ & $0.48 \pm 0.01$ & $1.20 \pm 0.02$ & $159.30 \pm 20.72$ & $249.74 \pm 32.23^{*}$ \\
\hline MER-DS & $10.73 \pm 0.13$ & $39.83 \pm 0.04^{*}$ & $3.42 \pm 0.04$ & $13.04 \pm 0.11^{*}$ & $1.33 \pm 0.02$ & $4.88 \pm 0.24^{*}$ & $287.10 \pm 19.45$ & $383.06 \pm 37.01$ \\
\hline MER-RF & $10.20 \pm 0.10$ & $38.57 \pm 0.19$ & $3.26 \pm 0.03$ & $12.47 \pm 0.12$ & $1.26 \pm 0.01$ & $4.74 \pm 0.22$ & $327.49 \pm 23.33^{*}$ & $372.05 \pm 35.42$ \\
\hline MxDA-DS & $10.07 \pm 0.12$ & $42.23 \pm 0.31^{*}$ & $3.20 \pm 0.04$ & $13.58 \pm 0.84^{*}$ & $0.56 \pm 0.01$ & $2.33 \pm 0.02^{*}$ & $259.14 \pm 11.31^{*}$ & $333.84 \pm 11.95$ \\
\hline MxDA-RF & $9.20 \pm 0.09$ & $40.27 \pm 0.25$ & $2.93 \pm 0.03$ & $13.24 \pm 0.11$ & $0.51 \pm 0.01$ & $2.22 \pm 0.01$ & $212.15 \pm 13.71$ & $319.69 \pm 2.07$ \\
\hline MxDL-DS & $12.70 \pm 0.25$ & $19.30 \pm 0.67^{*}$ & $4.04 \pm 0.08$ & $6.15 \pm 0.22^{*}$ & $0.99 \pm 0.02$ & $1.53 \pm 0.05^{*}$ & $252.05 \pm 17.95$ & $383.06 \pm 37.01$ \\
\hline MxDL-RF & $10.83 \pm 0.16$ & $18.50 \pm 0.76$ & $3.45 \pm 0.05$ & $5.89 \pm 0.24$ & $0.84 \pm 0.01$ & $1.47 \pm 0.06$ & $251.02 \pm 17.87$ & $372.05 \pm 35.42$ \\
\hline
\end{tabular}

Savanna: $M E L-R F=M$. elegans-Rainforest: $M E R-R F=M$. erythrophylla- Rainforest: MxDA-RF = M. "Doña Aurora" - Rainforest; $M x D L-R F=M$."Doña Luz" - Rainforest: * Significantly different at $P<0.05$ 

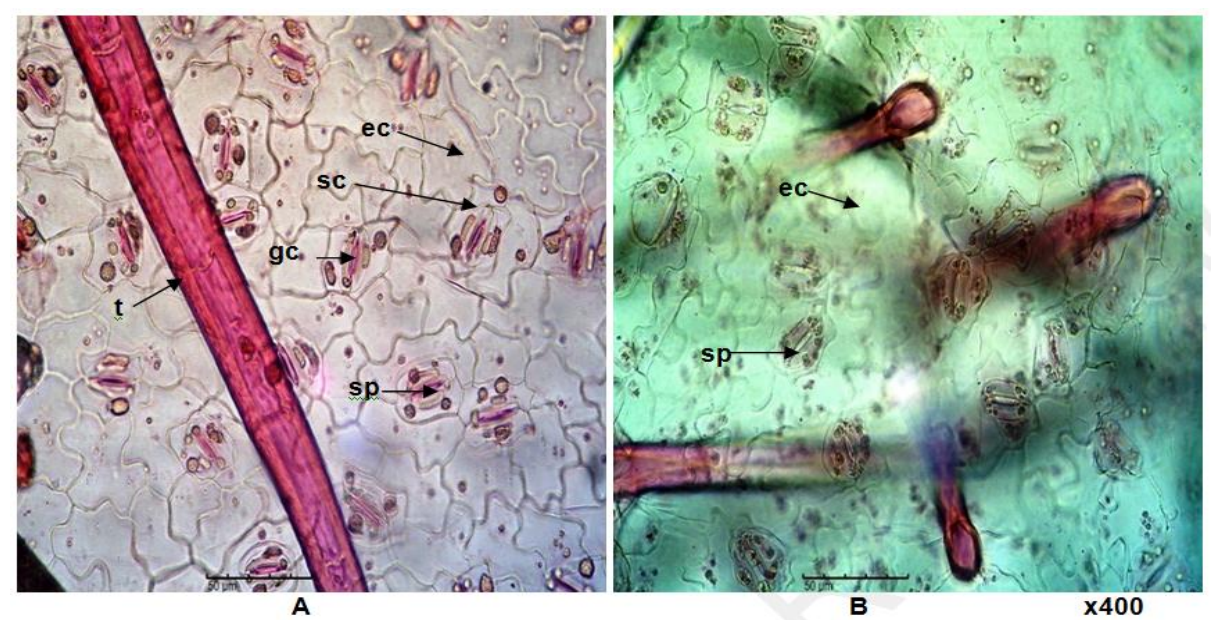

Plate 6. Abaxial surfaces of the leaves of (A): $M$. elegans and (B): $M$. erythrophylla $e c=$ epidermal cell; $s p=$ stomata pore; $g c=$ guard cell; $s c=$ subsidiary cell; $t=$ trichome
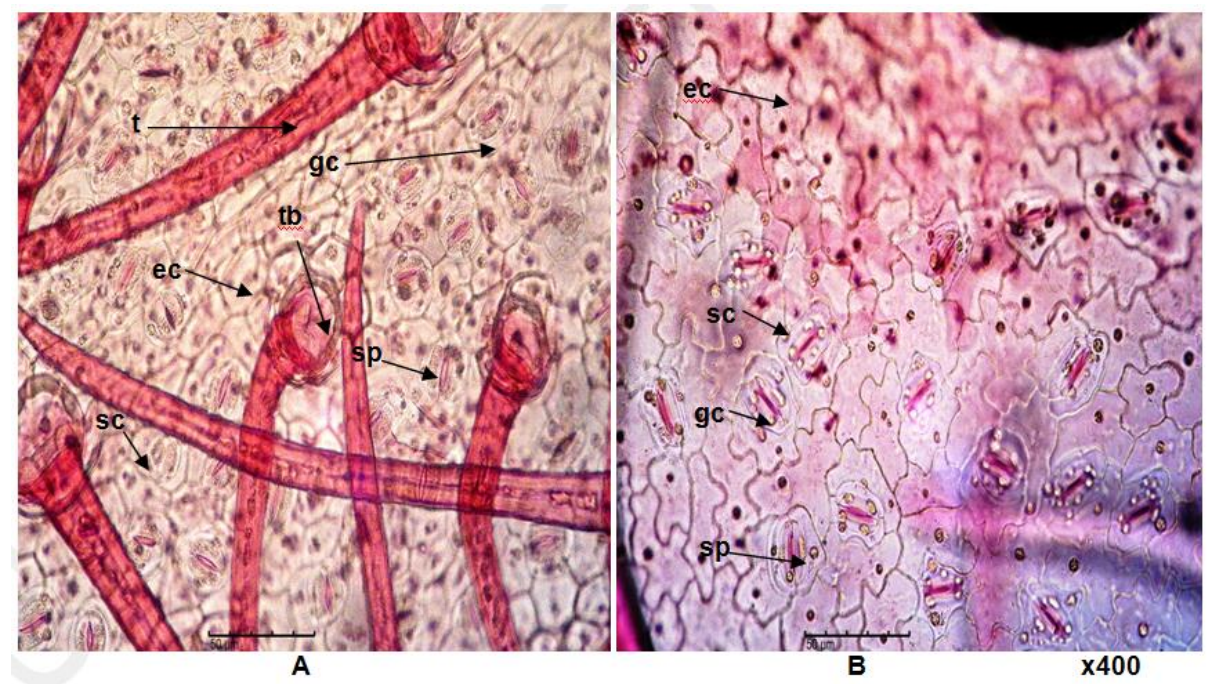

Plate 7. Abaxial surfaces of the leaves of (A): $M$. "Doña Aurora" and (B): $M$. "Doña Luz" $e c=$ epidermal cell; $s p=$ stomata pore; $g c=$ guard cell; $s c=$ subsidiary cell; $t=$ trichome; trichome base

Climatic conditions affected these variables as trichomes were more abundant in the specimens collected from Derived Savanna (drier) area. Leaf trichomes function in defence, but also affect gas exchange and temperature. In many plants, trichomes decrease the absorption of shortwave radiation by leaves and keep them cooler [21]. This could explain the reason for the higher density and size of trichomes in the leaves of samples collected from the Derived Savanna (drier) study location (Table 5). Trichomes also act as sinks for excess calcium and other minerals on polluted areas. This reduces stress to the plant $[21,35]$.

\section{CONCLUSION}

The results obtained from this study have shown that evidences from leaf epidermal studies could be used in delimitation of the four (two specific and two infraspecific) taxa of Mussaenda L. and other plant species while also are very promising potential indicators for environmental monitoring. The close resemblance of epidermal cells and stomata parameters between M. "Doña Aurora" and $M$. "Doña Luz" prove they are just variants of the same species. Similarities in their leaf epidermal features support their infrageneric relationship, while differences in structures have 
delimitation as distinct species/taxa. Further studies are suggested to employ other taxonomic evidences - phytochemistry, molecular systematics among others, to support the circumscription of this genus. Efforts should also be channeled towards utilizing these characters as environmental indicators in predicting climatic changes and environmental pollution.

\section{COMPETING INTERESTS}

Authors have declared that no competing interests exist.

\section{REFERENCES}

1. Kpadehyea JT, Buot Jr IE. Leaf architecture of two species and nine infraspecific taxa of the Philippine Mussaenda Linn. (Rubiaceae): Conservation concerns. Int Res J Biol Sci. 2014;3(10):13-21.

2. Jayaweera A. Adventitious root formation and development in cuttings of Mussaenda erythrophylla (L.) Schum. \& Thonn. Hort Sci. 1996;3(16):1023-1025.

3. Fresco MC. Mass propagating the Donas through Kolab System. Bart Today. 2001;3\&4.+

(Accessed 14 June 2017)

Available:http://www.bar.gov.ph/bardigest/ 2001/ocstdec01_massprop.asp

4. Ogbu JU. Ornamental Mussaenda spp. for Nigeria's gardens and landscape. Environment. Proceedings of the $45^{\text {th }}$ Annual Conference of the Agricultural Society of Nigeria (ASN). 2011;316-319.

5. Greensill TM. Gardening in the tropics. London: Evans Publishers; 1977.

6. Matthew IP, Karikari SK. Horticulture: principles and practices. Lagos: Macmillan; 1990.

7. Chadha KL, Choudhury B. Ornamental horticulture in India. New Delhi: ICAR; 2007.

8. Manandar NP, Manandar SP. Plants and People of Nepal. New Delhi: Timber Press; 2002.

9. Venkatesh K, Rao UU, Kiranmayi GVN, Naik RN, Mukharjee NSV, Vinay VNV, Phanindra K. Phytochemical screening and evaluation of diuretic activity of ethanolic and chloroform extracts of Mussaenda erythrophylla in rats. Int $\mathrm{J}$ Biol Pharma Res. 2013;4(1):8-10.

10. Vidyalakshmi KS, Charles DA, Hannah RV. Antimitotic and cytotoxic activity of
Mussaenda "Queen Sirikit". J Pharmacol Toxicol. 2007;2(7):660-665.

11. Rosario TL. Saga of a spontaneous mutant: Mussaenda 'Dona Aurora'. Philippine J Crop Sci. 2007;32(1):89-102.

12. Olosunde OM, Fawusi MOA. Effect of growing media on rooting of 'Queen of Philippines' (Mussaenda philippica A. Rich). In: Fasina AS, Olufolaji AO, Umeh VC, Editors. Lagos: Proceedings of Horticultural Society of Nigeria (HORTSON); 2003.

13. Pandey SN, Misra SP. Taxonomy of Angiosperms. NewDelhi: Ane Books Pvt; 2008.

14. Nwafor $\mathrm{FI}$, Orabueze $\mathrm{Cl}$. Role of phytochemistry in plant classification: Phytochemotaxonomy. In: Egbuna C, Ifemeje JC, Udedi SC, Kumar S, Editors. Phytochemistry, Volume 1: Fundamentals, Modern Techniques, and Applications. Canada \& UK: Apple Academic Press; 2019.

15. Sonibare MA, Adeniran AA. Comparative micromorphological study of wild and micropropagated Dioscorea bulbifera Linn. Asian Pacific J Trop Biomed. 2014;4(3): 176-183.

16. Hemcinschi A, Galeş R, Toma C. Vegetative anatomy of two Galium L. species (Rubiaceae). Biologie Vegetală. 2008;2:30-37.

17. Kala A, Soosairaj $S$, Raja $P$, Dhatchanamoorthy N. Micromorphological assessment and stem anatomy of Spermacoce species of Tamilnadu, India. Life Sciences Leaflets. 2013;8:19-28.

18. Evert RF. Esau's plant anatomy, Third Ed. London: John Wiley and Sons Inc.; 2006.

19. Ogbonna CE, Ugbogu AE, Otuu FC, Mbaogu NE, Johnson AR. Influence of rock quarrying activities on the physiochemical characteristics of selected edible fruit trees in Uturu, Abia State, Nigeria. Appl Ecol Environ Sci. 2017;5(1): 1-9.

20. Ogbonna CE, Nwafor FI, Ugbogu EA, Nwazue K. Assessment of foliar parameters and air pollution tolerance of broad leaved trees in Ugwuele quarry site, Uturu, Nigeria. Appl Ecol Environ Sci. 2018;6(2):48-56.

21. Gutschick VP. Biotic and abiotic consequences of differences in leaf structure. New Phytol. 1999;143:3-18. 
22. Petrova $\mathrm{Y}$. The effect of light intensity on the stomatal density of lavender (Lavandula angustifolia). Young Scientists Journal. 2012;12:89-93.

23. Camargo MAB, Marenco RA. Density, size and distribution of stomata in 35 rainforest tree species in Central Amazonia. Acta Amazonica. 2011;41(2):205-212.

24. Ofomata GEK. Soil erosion in Nigeria: The views of a geomorphologist. Inaugural Lecture Series No 7. University of Nigeria, Nsukka; 1985.

25. Nwite JN, Obi ME. Quantifying the productivity of selected soils in Nsukka and Abakaliki, Southeastern Nigeria using productivity index. J Trop Agric Food Environ Ext. 2008;7(3):170-178.

26. Hutchinson J, Dalziel JM. Flora of West Tropical Africa, Volume II, $2^{\text {nd }}$ Ed. London: Crown Agent for Oversea Governments and Administrations; 1963.

27. Kew Herbarium Catalogue. Royal Botanic Gardens Kew.

(Accessed 14 June 2017)

Available:http://apps.kew.org/herbcat/navig ator.do

28. The New York Botanic Garden. Database. (Accessed 20 June 2017)

Available:https://www.nybg.org/bsci/online pubs.html

29. Obembe OA. Studies on the stomata of some Rubiaceae. Acad Res Int. 2015;6(4): 17-23.
30. AbdulRahaman AA, Oladele FA. Stomata, trichomes and epidermal cells as diagnostic features in six species of Genus Ocimum L. (Lamiaceae). Nig J Bot. 2005;18:214-223.

31. Stuart G. Philippine alternative medicine; 2016.

(Accessed on 27th June, 2016)

Available:http://www.stuartxchange.com/

32. Ahmad K, Khan MA, Ahmad M, Shaheen $\mathrm{N}$, Nazir A. Taxonomic diversity in epidermal cells of some sub-tropical plant species. Int. J. Agric. Biol. 2010;12:115118.

33. Kolawole OS, Jimoh MA, Yakubu F, Chukwuma EC. Taxonomic value of the leaf micro-morphology andquantitative phytochemistry of Jatropha integerrima Jacq. And Jatropha podagrica Hook. (Euphorbiaceae)- known horticultural plants in Nigeria. Anales de Biologia. 2017;39:55-62.

34. Bishay DW, Backheet EY, Gouda YG, Moustafa SM. Macro- and micromorphology of the leaf, stem, stem bark and flower of Vangueria edulis cultivated in Egypt. Bull Pharm Sci. 2017;34(1): 53-76.

35. De Silva DLR, Hetherington AM, Mansfield TA. Where does all calcium go? Evidence of an important regulatory role for trichomes in two calcicoles. Plant Cell Environ. 1996;19:880-886.

(c) 2019 Nwafor et al.; This is an Open Access article distributed under the terms of the Creative Commons Attribution License (http://creativecommons.org/licenses/by/4.0), which permits unrestricted use, distribution, and reproduction in any medium, provided the original work is properly cited.

Peer-review history:

The peer review history for this paper can be accessed here: http://www.sdiarticle3.com/review-history/47057 